\title{
A Study of the Association of Polymorphism rs5860110 and its Protective Role against Ankylosing Spondylitis in a Chinese Population
}

\author{
Xiufang Wang and Zhaoqing Zhang* \\ Department of Rehabilitation, The Third Hospital of Wuhan, Wuhan, Hubei Province, 430060, China \\ *For correspondence: Email: 187076605@qq.com
}

Received: 8 June $2014 \quad$ Revised accepted: 18 August 2014

\begin{abstract}
Purpose: To investigate whether secreted phosphoprotein-1 (SPP1) promoter variants are associated with susceptibility to ankylosing spondylitis (AS) in the western China.

Methods: The rs5860110 variant of SPP1 promoter was genotyped using direct sequencing in 120 unrelated AS patients and 106 ethnically matched healthy controls. All the patients were human leukocyte antigen (HLA) -B27 positive. Frequencies of different genotypes and alleles were analyzed among the AS patients and the controls.

Results: In AS patient group, frequency of +254 SPP1 promoter genotype was 0.483 in base TG/TG homozygotes and 0.517 in TG-(deletion)/TG-(deletion) homozygotes, while the values for the control group were 0.311 and 0.689 , respectively. However, TG-(deletion)/TG heterozygote was not detected in this study. The rs5860110 single nucleotide polymorphism (SNP) in SPP1 was significantly different when all $A S$ patients were compared to controls $(p<0.01)$.

Conclusion: The rs5860110 SNP in SPP1 has a protective role against AS in the selected Chinese population.
\end{abstract}

Keywords: Polymorphism, Ankylosing spondylitis, Secreted phosphoprotein-1, Sequencing, Genotype, Alleles

Tropical Journal of Pharmaceutical Research is indexed by Science Citation Index (SciSearch), Scopus, International Pharmaceutical Abstract, Chemical Abstracts, Embase, Index Copernicus, EBSCO, African Index Medicus, JournalSeek, Journal Citation Reports/Science Edition, Directory of Open Access Journals (DOAJ), African Journal Online, Bioline International, Open-J-Gate and Pharmacy Abstracts

\section{INTRODUCTION}

Ankylosing spondylitis (AS) is a chronic inflammatory disorder characterized by inflammation in the spine and sacroiliac joints causing initial bone and joint erosion and subsequent ankylosis [1]. Most patients develop first symptoms of AS younger than 30 years of age [2]. More recent studies have shown that structural damage at initial presentation is the best predictor of further damage [3-5].

Secreted phosphoprotein-1 (SPP1, located on $4 q 21-q 25)$ is a secreted arginine-glycine- aspartate (RGD)-containing phosphoprotein with cell-adhesive and chemotactic properties both in vitro and in vivo [6]. SPP1 mainly contributes to host defence, bone formation, and wound healing by stimulating macrophage migration as well as protecting against viral and bacterial infections through its pro-Th1 effect [7]. It has been shown that The SPP1 polymorphisms were associated with susceptibility to systemic lupus erythematosus (SLE) [8-10]. In addition, it was associated with many types of cancer, such as nasopharyngeal carcinoma [11], colorectal carcinoma [12], breast cancer [13], non-small-cell lung cancer [14], gastric cancer [15]. These 
results indicate that $S P P 1$ can act as a diagnostic marker.

AS patients' disease severity is largely genetically determined [16]. However, there are no relative reports about the relationship between SPP1 polymorphisms and risk of AS currently. Previous study has confirmed that SPP1 is overexpressed and with higher levels in the AS patients compared with controls $[17,18]$. Therefore, the aim of the present study was to examine the polymorphism of SPP1 rs5860110 for an association with AS in humans in an effort to determine whether there is any evidence that a genetic predisposition to altered SPP1 expression might explain the overexpression seen in human AS patients.

\section{EXPERIMENTAL}

\section{Subjects}

From May 2010 to October 2012, 120 unrelated AS patients (78 men and 42 women, the average was $39.5 \pm 10.3$ years, range from 18 to 52 years. All the patients were HLA-B27 positive) and 106 normal control (71 men and 35 women, the average was $35.8 \pm 11.5$ years, range from 15 to 48 years), were recruited after giving written informed consent. This study was approved by Ethics Committee of Autonomous Region people's Hospital (approval ref no. 20100301) [19]. Three milliliters of fasting venous blood was collected from all subjects, and then the serum and blood clotting were separated. Genomic DNA was extracted from white blood cells via phenol and chloroform extraction ethanol precipitation essentially following standard protocols.

\section{Analysis of polymorphisms in the SPP1 regulatory region}

The rs5860110 SNP was genotyped by direct sequencing of the sense and anti-sense strands following polymerase chain reaction (PCR) amplification of the promoter regulatory region 27 to +584 . PCR was performed using $50 \mathrm{ng}$ DNA as a template under the following conditions: $95^{\circ} \mathrm{C}$ for $7 \mathrm{~min}$, then 30 cycles of 94 ${ }^{\circ} \mathrm{C}$ for $50 \mathrm{~s}$, an annealing temperature for $60 \mathrm{~s}$, and $72{ }^{\circ} \mathrm{C}$ for $60 \mathrm{~s}$, with a final extension at $72{ }^{\circ} \mathrm{C}$ for $10 \mathrm{~min}$. The PCR products were subjected to cycle sequencing with the respective forward and reverse primer using an automated $\mathrm{ABI} 3100$ DNA sequencer by GeneCore Bio Technologies (Shanghai China).

\section{Statistical analysis}

Statistical analysis was performed using SPSS 11.5 software. One-way ANOVA and t-test was used to compare mean differences for continuous variables. Allele frequency was determined via direct counting. The distribution of genotypes in the AS patients and control were obtained using a Chi-square test, and significance was defined as $p<0.05$.

\section{RESULTS}

\section{Gene deletion and polymorphism}

Direct sequencing of DNA fragments from the promoter regulatory region -27 to +584 in AS patients and controls. In AS patients group, frequency of +254 SPP1 promoter genotype was 0.483 in TG/TG homozygotes and 0.517 in TG(deletion)/TG-(deletion) homozygotes, and the control group was 0.311 and 0.689 , respectively, but the TG-(deletion)/TG heterozygote was not detected in this study (Figure 1).
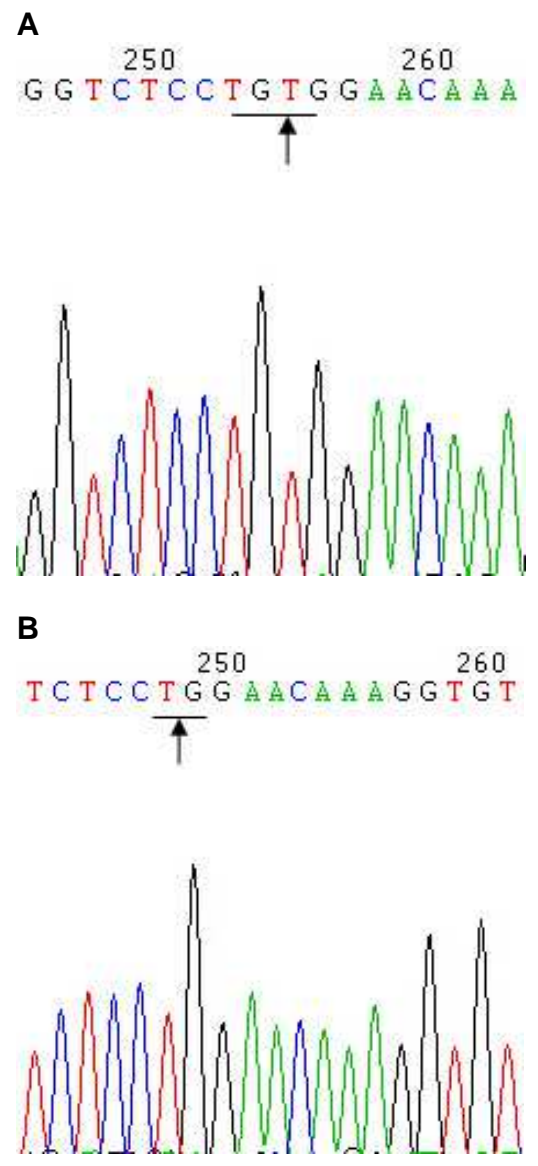

Figure 1: Schematic diagram and sequencing data of the SPP1 promoter. Note: A = TG/TG homozygotes; B $=\mathrm{TG}$-(deletion)/TG-(deletion) homozygotes 
Table 1: Allele frequency of SPP1 promoter polymorphism detected in AS patients and controls

\begin{tabular}{|c|c|c|c|c|c|c|}
\hline SNP & Reference SNP & Allele & $\begin{array}{l}\text { Frequency in } \\
\text { AS patients }\end{array}$ & $\begin{array}{l}\text { Frequency in } \\
\text { controls }\end{array}$ & Chi-square & P-value \\
\hline c.244_245ins TG & rs5860110 & $\overline{\mathrm{TG}}$ & $\begin{array}{l}62(0.517) \\
58(0.483)\end{array}$ & $\begin{array}{l}73(0.689) \\
33(0.311)\end{array}$ & 6.924 & 0.009 \\
\hline
\end{tabular}

Compared with the controls, $p<0.01$

\section{SPP1 promoter polymorphism is associated with AS susceptibility}

As shown in Table 1. The del TG frequency was significantly increased in controls (0.689) compared to AS patients (0.517) $(p<0.01)$, indicating that the haplotype del TG has a protective role against $A S$.

\section{DISCUSSION}

The pathogenesis of AS remains poorly understood. However, genetic factors play a significant role [20]. Single nucleotide polymorphisms (SNP) of the human SPP1 gene has been reported to be associated with many diseases [21-23]. Based on my knowledge, it is first time to report the relationship between SPP1 polymorphism and AS patients.

In this study, we have investigated the difference in SPP1 gene polymorphisms between AS patients and healthy controls. In AS patients group, frequency of rs5860110 was 0.483 in TG/TG homozygotes and 0.517 in TG(deletion)/TG-(deletion) homozygotes, and the control group was 0.311 and 0.689 , respectively, but the TG-(deletion)/TG heterozygote was not detected. The del TG frequency was significantly increased in controls compared to AS patients ( $p$ $<0.01$ ), indicating that the haplotype del TG has a protective role against $A S$. The studies about the rs5860110 SNP was ralately few. The rs5860110 frequnency was 0.672 in TG(deletion)/TG-(deletion) homozygotes in a german pseudoxanthoma elasticum (PXE) patients, and 0.801 in controls, the SNP could be interpreted as a genetic risk pattern for PXE [24]. A study found that The rs5860110 SNP was not associated with type 1 daiabetic patients in Italy [25].

So far, genetic variants in the SPP1 gene have shown to be involved in susceptibility to other immune-mediated diseases such as SLE [8,9], oligoarticular juvenile idiopathic arthritis [26] and sarcoidosis [27]. Despite promising functional data, previous genotype analyses could not confirm SPP1 as significant disease modifying gene in classical Th17-mediated diseases such as multiple sclerosis $[28,29]$ and rheumatoid arthritis [30]. However, it is first time to report the relationship between SPP1 polymorphism and AS patients. So the research should be confirmed in large and ethnically divergent population samples to make stronger conclusion about the association between the rs5860110 SNP with the AS.

\section{CONCLUSION}

This study demonstrates that genetic polymorphisms in the SPP1 gene are associated with susceptibility to AS and that rs5860110 SNP has a protective role against ankylosing spondylitis in a Chinese population. This relationship is being reported for the first time.

\section{ACKNOWLEDGEMENT}

This research was supported by The Third Hospital of Wuhan, China.

\section{REFERENCES}

1. Brown MA, Wordsworth BP, Reveille JD. Genetics of ankylosing spondylitis. Clin Exp Rheumatol 2002; 20: S43-49.

2. Braun J, Sieper J. Ankylosing spondylitis. Lancet 2007; 369: 1379-1390.

3. Carette S, Graham D, Little H, Rubenstein J, Rosen P. The natural disease course of ankylosing spondylitis. Arthritis Rheum 1983; 26: 186-190.

4. Gran JT, Skomsvoll JF. The outcome of ankylosing spondylitis: a study of 100 patients. Br J Rheumatol 1997; 36: 766-771.

5. Wanders A, Landewé $R$, Spoorenberg A, de Vlam K, Mielants $H$, Dougados $M$, van der Linden $S$, van der Heijde $D$. Scoring of radiographic progression in randomised clinical trials in ankylosing spondylitis: a preference for paired reading order. Ann Rheum Dis 2004; 63: 1601-1604.

6. Oldberg A, Franzen A, Heinegard D. Cloning and sequence analysis of rat bone sialoprotein (osteopontin) cDNA reveals an Arg-Gly-Asp cellbinding sequence. Proc Natl Acad Sci USA 1986; 83: 8819-8823.

7. Shin HD, Park BL, Cheong HS, Yoon JH, Kin YJ, Lee HS. SPP1 polymorphisms associated with HBV clearance and HCC occurrence. Int $J$ Epidemiol 2007; 36: 1001-1008.

Trop J Pharm Res, September 2014; 13(9): 1547 
8. DAlfonso S, Barizzone N, Giordano M, Chiocchetti A, Magnani $C$, Castelli $L$, Indelicato $M$, Giacopelli $F$, Marchini $M$, Scorza $R$, et al. Two single-nucleotide polymorphisms in the $5^{\prime}$ and $3^{\prime}$ ends of the osteopontin gene contribute to susceptibility to systemic lupus erythematosus. Arthritis Rheum 2005; 52: 539-547.

9. Xu AP, Bai J, Lu J, Liang YY, Li JG, Lai DY, Wan X, Huang $\mathrm{HH}$. Osteopontin gene polymorphism in association with systemic lupus erythematosus in Chinese patients. Chin Med J (Engl) 2007; 120: 2124-2128.

10. Trivedi T, Franek BS, Green SL, Kariuki SN, Kumabe M, Mikolaitis RA, Jolly M, Utset TO, Niewold TB. Osteopontin alleles are associated with clinical characteristics in systemic lupus erythematosus. J Biomed Biotechnol 2011; 2011: 802581-802586.

11. Wang J, Nong L, Wei $Y$, Qin S, Zhou $Y$, Tang $Y$. Association of osteopontin polymorphisms with nasopharyngeal carcinoma risk. Hum Immunol 2014; 75: 76-80.

12. Fan $Y$, Zhang $X$, Yang $Z H$, Sun $X W$, Li SN, Zhong $L$, Cheng $X$, Wang $Y, M a Y R$. The polymorphisms of osteopontin gene and plasma osteopontin protein levels with susceptibility to colorectal carcinoma. DNA Cell Biol 2013; 32: 594-600.

13. Ramchandani D, Weber GF. An osteopontin promoter polymorphism is associated with aggressiveness in breast cancer. Oncol Rep 2013; 30: 1860-1868.

14. Chen Y, Liu H, Wu W, Li Y, Li J. Osteopontin genetic variants are associated with overall survival in advanced non-small-cell lung cancer patients and bone metastasis. J Exp Clin Cancer Res 2013; 32: 45-50.

15. Zhao $F$, Chen $X$, Meng $T$, Hao B, Zhang Z, Zhang G. Genetic polymorphisms in the osteopontin promoter increases the risk of distance metastasis and death in Chinese patients with gastric cancer. BMC Cancer 2012; 12: 477-483.

16. Hamersma J, Cardon LR, Bradbury L, Brophy S, van der Horst-Bruinsma I, Calin A, Brown MA. Is disease severity in ankylosing spondylitis genetically determined? Arthritis Rheum 2001; 44: 1396-1400.

17. Choi ST, Kim JH, Kang EJ, Lee SW, Park MC, Park YB, Lee SK. Osteopontin might be involved in bone remodeling rather than in inflammation in ankylosing spondylitis. Rheumatology (Oxford) 2008; 47: 17751779.

18. Genre F, López-Mejías R, Miranda-Filloy JA, Ubilla B, Carnero-López B, Gómez-Acebo I, Blanco R, Ochoa $R$, Arias-Bajo M, Rueda-Gotor J, et al. Correlation between two biomarkers of atherosclerosis, osteopontin and angiopoietin-2, in nondiabeticankylosing spondylitis patients undergoing TNF- $\alpha$ antagonist therapy. Clin Exp Rheumatol 2014; 32: $231-236$
19. World Medical Association. World Medical Association Declaration of Helsinki: Ethical Principles for Medical Research Involving Human Subjects. Seoul: From the 59th World Medical Association Assembly, 2008. http://www.wma.net/en/30publications/10policies/b3/1 7c.pdf.

20. Reveille JD, Ball EJ, Khan MA. HLA-B27 and genetic predisposing factors in spondyloarthropathies. Curr Opin Rheumatol 2001; 13: 265-272.

21. Hou $X, H u Z$, Huang $X$, Chen $Y$, He $X, X u$ H, Wang $N$. Serum osteopontin, but not OPN gene polymorphism, is associated with $\mathrm{LVH}$ in essential hypertensive patients. J Mol Med (Berl) 2014; 92: 487-495.

22. Jing M, Li B, Hou X, Shoba J, Li C, Liang H, Zhang X, Liu $E$, Yang B, Meng X.OPN gene polymorphism and the serum OPN levels confer the susceptibility and prognosis of ischemic stroke in Chinese patients. Cell Physiol Biochem 2013; 32:1798-1807.

23. Karamizadeh Z, Kamali Sarvestani E, Saki F, Karamifar $H$, Amirhakimi GH, Namavar Shooshtarian $\mathrm{MH}$, Ashkani-Esfahani S. Investigation of osteopontin levels and genomic variation of osteopontin and its receptors in Type 1 diabetes mellitus. J Endocrinol Invest 2013; 36: 1090-1093.

24. Hendig D, Arndt M, Szliska C, Kleesiek K, Götting C. SPP1 promoter polymorphisms: identification of the first modifier gene for pseudoxanthoma elasticum. Clin Chem 2007; 53: 829-836.

25. Marciano R, DAnnunzio G, Minuto N, Pasquali $L$, Santamaria A, Di Duca M, Ravazzolo R, Lorini $R$. Association of alleles at polymorphic sites in the Osteopontin encoding gene in young type 1 diabetic patients. Clin Immunol 2009; 131: 84-91.

26. Marciano R, Giacopelli F, Divizia MT, Gattorno M, Felici E, Pistorio A, Martini A, Ravazzolo R, Picco P. A polymorphic variant inside the osteopontin gene shows association with disease course in oligoarticular juvenile idiopathic arthritis. Ann Rheum Dis 2006; 65: 662-665.

27. Maver A, Medica I, Salobir B, Tercelj M, Peterlin B. Genetic variation in osteopontin gene is associated with susceptibility to sarcoidosis in Slovenian population. Dis Markers 2009; 27: 295-302.

28. Hensiek AE, Roxburgh $R$, Meranian M, Seaman S, Yeo $T$, Compston DA, Sawcer SJ. Osteopontin gene and clinical severity of multiple sclerosis. J Neurol 2003; 250: 943-947.

29. Mas $A$, Martínez A, de las Heras $V$, Bartolomé $M$, de la Concha EG, Arroyo R, Urcelay E. The 795CT polymorphism in osteopontin gene is not associated with multiple sclerosis in a Spanish population. Mult Scler 2007; 13: 250-252.

30. Urcelay E, Martínez A, Mas-Fontao A, Peris-Pertusa A, Pascual-Salcedo D, Balsa A, Fernández-Arquero $M$, dela Concha E. Osteopontin gene polymorphisms in Spanish patients with rheumatoid arthritis. J Rheumatol 2005; 32: 405-409. 